\title{
Identification of a Potent Endothelium-Derived Angiogenic Factor
}

\author{
Vera Jankowski ${ }^{1}$, Markus Tölle ${ }^{1}$, Thi Nguyet Anh Tran ${ }^{1}$, Markus van der Giet ${ }^{1}$, Mirjam Schuchardt ${ }^{1}$, \\ Kerstin Lehmann ${ }^{2}$, Doreen Janke ${ }^{2}$, Burkhard Flick ${ }^{3}$, Alberto Arduan Ortiz ${ }^{4}$, Niño Maria Dolores Sanchez ${ }^{5}$, \\ Martin Tepel $^{6}$, Walter Zidek ${ }^{1}$, Joachim Jankowski ${ }^{{ }^{*}}$ *
}

1 Charité-Universitaetsmedizin Berlin, Medizinische Klinik IV (CBF), Berlin, Germany, 2 Julius Wolff Institute and Berlin-Brandenburg Center for Regenerative Therapies, Charite - Universitaetsmedizin Berlin, Berlin, Germany, 3 Charité-Universitaetsmedizin Berlin, Institute of Toxicology (CBF), Berlin, Germany, 4 IIS-Fundacion Jimenez DiazUAM and IRSIN, Madrid, Spain, 5 IdiPAZ, Madrid, Spain, $\mathbf{6}$ University of Southern Denmark, Institute of Molecular Medicine, Odense, Denmark

\begin{abstract}
The secretion of angiogenic factors by vascular endothelial cells is one of the key mechanisms of angiogenesis. Here we report on the isolation of a new potent angiogenic factor, diuridine tetraphosphate $\left(U \mathrm{p}_{4} \mathrm{U}\right)$ from the secretome of human endothelial cells. The angiogenic effect of the endothelial secretome was partially reduced after incubation with alkaline phosphatase and abolished in the presence of suramin. In one fraction, purified to homogeneity by reversed phase and affinity chromatography, $\mathrm{Up}_{4} \mathrm{U}$ was identified by MALDI-LIFT-fragment-mass-spectrometry, enzymatic cleavage analysis and retention-time comparison. Beside a strong angiogenic effect on the yolk sac membrane and the developing rat embryo itself, $U p_{4} \mathrm{U}$ increased the proliferation rate of endothelial cells and, in the presence of PDGF, of vascular smooth muscle cells. U $p_{4} \mathrm{U}$ stimulated the migration rate of endothelial cells via P2Y2-receptors, increased the ability of endothelial cells to form capillary-like tubes and acts as a potent inducer of sprouting angiogenesis originating from gel-embedded EC spheroids. Endothelial cells released $U p_{4} U$ after stimulation with shear stress. Mean total plasma Up $\mathrm{U}_{4}$ concentrations of healthy subjects $(\mathrm{N}=6)$ were sufficient to induce angiogenic and proliferative effects $\left(1.34 \pm 0.26 \mathrm{nmol} \mathrm{L}^{-1}\right)$. In conclusion, $\mathrm{Up}_{4} \mathrm{U}$ is a novel strong human endothelium-derived angiogenic factor.
\end{abstract}

Citation: Jankowski V, Tölle M, Tran TNA, van der Giet M, Schuchardt M, et al. (2013) Identification of a Potent Endothelium-Derived Angiogenic Factor. PLoS ONE 8(7): e68575. doi:10.1371/journal.pone.0068575

Editor: Hiromi Yanagisawa, UT-Southwestern Med Ctr, United States of America

Received April 17, 2013; Accepted May 29, 2013; Published July 29, 2013

Copyright: (c) 2013 Jankowski et al. This is an open-access article distributed under the terms of the Creative Commons Attribution License, which permits unrestricted use, distribution, and reproduction in any medium, provided the original author and source are credited.

Funding: This study was supported by a grant from the German Research Foundation (DFG, Ja-972/11-1; JJ), the Sonnenfeld Foundation (JJ; VJ) and Federal Ministry of Education and Research (BMBF; 01GR0807 (JJ)). The author (VJ; J) was supported by grants FP7-HEALTH24 2009-2.4.5-2 to "SYSKID" (241544) and "HEALTH 2011.2.4.2-2" to "Mascara" (278249) from the European Union. Eutox, FIS PS09/00447, ISCIII-RETIC REDinREN/RD12/0021/0001 and 0004. Comunidad de Madrid/S2010/BMD-2378(NMDS; AAO); FIS-Sara Borrell to MDSN, Programa Intensificación Actividad Investigadora (ISCIII/Agencia Laín-Entralgo/CM) (AAO). VJ received a grant from the Else-Kroener-foundation. The funders had no role in study design, data collection and analysis, decision to publish, or preparation of the manuscript.

Competing Interests: The authors have declared that no competing interests exist.

* E-mail: Joachim.Jankowski@charite.de

\section{Introduction}

Vasculature in adult mammals is mainly quiescent; however, new blood vessel formation is required for timely tissue repair and remodeling after injury [1]. The formation of new blood vessels is an essential process in the life of higher organisms. Development, reproduction, wound healing, communication of humoral signals, transport of nutrients and waste products all require angiogenesis [2]. The process of angiogenesis involves migration, proliferation, differentiation, and adhesion of multiple cell types, including endothelial, mural, and inflammatory cells [3,4].

However, disease processes such as cancer growth [5], diabetic retinopathy or chronic inflammation are also dependent on angiogenesis [6]. Hence, the humoral mechanisms of angiogenesis have attracted increasing interest [7]. Among those, interest has focused on peptidic angiogenic factors such as the vascular endothelial growth factors, hepatocyte growth factor or fibroblast growth factor, and non-peptidic, low molecular angiogenic factors such as adenosine or hypoxic metabolites, e. g. lactate or pyruvate, which mediate hypoxia-induced angiogenesis. Although various cell types are required in the humoral regulation of angiogenesis; the contribution of vascular endothelial cells is probably the most important. However, our knowledge about the mediators secreted by endothelial cells inducing angiogenesis is just at the beginning. Unravelling these mediators involved in angiogenesis would offer therapeutic options to ameliorate disorders that are currently leading causes of mortality and morbidity, including cardiovascular diseases, cancer, chronic inflammatory disorders, diabetic retinopathy, excessive tissue defects, and chronic non-healing wounds. The knowledge of the endogenous mediators involved provides numerous opportunities for therapeutic intervention [8].

Therefore, we screened the secretome of human endothelial cell cultures for further, yet unknown angiogenic factors by using the culture of rat embryos including their yolk sac with its developing vascular system. The embryos were cultured during organogenesis, when angiogenesis is a fundamental process $[9,10]$. The whole embryo culture (WEC) has been used before to study different growth factors, e.g. vascular endothelial growth [11], or to demonstrate the impact of different genes involved in angiogenesis [12]. We showed that incubation with alkaline phosphatase just partly reduced and blockade of purine P2 receptors markedly reduced the angiogenic effect of the endothe- 
lial secretome. Subsequently, diuridine tetraphosphate $\left(\mathrm{Up}_{4} \mathrm{U}\right)$ was identified as the responsible angiogenic factor.

\section{Materials and Methods}

\section{Chemicals}

HPLC water (gradient grade) and acetonitrile were purchased from Merck (Germany), all other substances from Sigma Aldrich (Germany).

\section{Culture of Endothelial Cells}

Human endothelial cells from dermal microvessels (HMEG-1) present the first immortalized human microvascular endothelial cell line that retains the morphologic, phenotypic, and functional characteristics of normal human microvascular endothelial cells [13]. These cells were cultured in MCDB 131 medium supplemented with $100 \mathrm{U} \mathrm{ml}^{-1}$ penicillin/streptomycin, $1 \%(\mathrm{v} / \mathrm{v}) \mathrm{L}-$ glutamine and $7.5 \%(\mathrm{v} / \mathrm{v})$ fetal bovine serum. Experiments comparing the phenotypic characteristics of HMEC-1 cells with human dermal microvascular endothelial cells or human umbilical vein endothelial cells revealed that HMEC-1 cells show features of both, small- and large-vessel endothelial cells [13]. On day 0 cells were placed into $175 \mathrm{~cm}^{2}$ cell-culture flasks (Nunc Inc., Germany) and were stimulated on day 2 at approximately $70 \%$ confluency. Confluent cultures of HMEC-1 cells showed typical cobblestone appearance and were further characterized by the expression of Willebrand factor, endothelial nitric oxide synthase, VEGF receptor 1 (FLT-1) and absence of smooth muscle $\alpha$-actin staining [14]. Primary human umbilical vein endothelial cells (HUVEC) were commercially obtained (Promocell, Germany) and expanded with endothelial growth medium (Promocell, Germany). Experiments were performed with cells grown for no more than four passages.

\section{Stimulation of Cultured Endothelial Cells}

Cell-culture flasks of endothelial cells $(\mathrm{n}=30)$ were washed three times with a physiological salt solution. After addition of $15 \mathrm{ml}$ physiological salt solution, the cell-culture flasks of endothelial cells were exposed to shear stress for $10 \mathrm{~min}$ by using a horizontally shaking machine [15]. The supernatant was collected and pooled after shear stress stimulation. Aliquots of the resulting supernatants were incubated with immobilized alkaline phosphatase as described earlier [16]. The supernatant was deproteinized with perchloric acid (final concentration $0.6 \mathrm{~mol} \mathrm{~L}^{-1}$ ) and centrifuged (3,500 $\left.\mathrm{U} \mathrm{min}^{-1} ; 4^{\circ} \mathrm{C} ; 5 \mathrm{~min}\right)$. Perchloric acid was precipitated by adding $\mathrm{KOH}(\mathrm{pH}$ 9.5). The precipitated proteins and the insoluble reaction product $\mathrm{KClO}_{4}$ were removed by centrifugation $\left(3,500 \mathrm{U} \mathrm{min}{ }^{-1} ; 4^{\circ} \mathrm{C} ; 5 \mathrm{~min}\right)$. Aliquots of the supernatant were neutralized before testing in the bioassay. For control reactions, 30 cell-culture flasks of endothelial cells were washed three times with $15 \mathrm{ml}$ of a physiological salt solution by avoiding mechanical stress. Salt solution was added extremely slowly. After washing, $15 \mathrm{ml}$ physiological salt solution was added to the endothelial cells. 10 min later, the supernatant was collected and pooled.

\section{Application of Shear Stress by Cone-and-plate Viscometer}

Cultured human umbilical vein endothelial cells (HUVEC) were subjected to shear stress in a cone-and-plate viscometer $[17,18]$. The secretome of HUVEC exposed to 1 dyn $\mathrm{cm}^{-2}$ (low, $0.1 \mathrm{~N} \mathrm{~m}^{-2}$ ) and $30 \mathrm{dyn}^{-2}$ (high, $3.0 \mathrm{~N} \mathrm{~m}^{-2}$ ) shear stress for $24 \mathrm{~h}$ were compared to the secretome of static control cells $\left(0 \mathrm{dyn} \mathrm{cm}^{-2}\right)$. Cell culture medium supplemented with 5\% dextran T-70 (SigmaAldrich, Germany) was added to the cell culture medium $1 \mathrm{~h}$ prior to biomechanical stimulation to increase the viscosity 2.95 -fold to $0.02065 \mathrm{dyn} \mathrm{s}^{-1} \mathrm{~cm}^{-2}$. Dextran had no influence on the expression of genes studied.

\section{Whole Embryo Culture (WEC)}

This study was approved by the "Ethical Committee Charite". All animal procedures conducted were in accordance with the guideline for the care and use of laboratory animals by the "Research Institute of Experimental Medicine" (FEM) of the Charité (Germany), approved by the "Ethical Committee Charitê". Wistar rats unilever (Bor:isw/SPF, TNO; Harlan-Winkelmann, Germany) were kept under specific pathogen-free conditions at a constant day and night cycle of 12 hours starting at 9:00 a.m. and 9.00 p.m and the following $24 \mathrm{~h}$ were designated as day 0 of pregnancy when sperm was detected in the vaginal smear.

On gestational day 9.5, the gravid rats were sacrificed by decapitation and the rat embryos were prepared and cultured according to a method previously published in detail [19]. The preparation of the embryos was performed in HBSS, they were placed in groups of four into sealed culture flasks $(50 \mathrm{ml})$ containing $7 \mathrm{ml}$ of the culture medium. The culture medium consists of 15\% HBSS and 85\% donor bovine serum (Quad Five, USA), supplemented with $1.57 \mathrm{mg} \mathrm{ml}{ }^{-1}$ D-glucose (Merck Eurolab, Germany) and $75 \mu \mathrm{g} \mathrm{ml}^{-1}$ L-methionine (Sigma-Aldrich, Germany). For incubation the culture flasks were placed for $48 \mathrm{~h}$ into a roller device (Memmert, Germany) at a speed of $25 \mathrm{rpm}$ and a temperature of $38.5^{\circ} \mathrm{C}$. Initiating the culture, the flasks were gassed with $10 \% \mathrm{O}_{2}, 5 \% \mathrm{CO}_{2}$, and $85 \% \mathrm{~N}_{2}$. After $36 \mathrm{~h}$ the oxygen concentration was raised to $50 \%$.

After $48 \mathrm{~h}$ of culture the embryos were evaluated for their growth (crown-rump length and protein content) and their differentiation (number of somites and morphological score) [19] using a dissection microscope. Finally the development of the yolk sac was estimated with special attention to its blood vessels system. After the morphological evaluation of the cultured embryos and their corresponding yolk sacs these tissues have been frozen and immediately stored at $-80^{\circ} \mathrm{C}$.

\section{Chromatographic Analysis of the Supernatants of Endothelial Cells}

Supernatants of stimulated endothelial cells were fractionated by a series of reversed-phase and affinity chromatographic steps. Triethylammonium acetate $\left(40 \mathrm{mmol} \mathrm{L}^{-1}\right.$ final concentration) was added to the supernatants. $\mathrm{pH}$ was titrated to 6.5. Next, two C18 reversed-phase columns (Chromolith Performance, RP C18e, $100 \times 4.6 \mathrm{~mm}$, Merck, Germany) connected in series were used to concentrate the supernatant of stimulated and unstimulated endothelial cells. Non-binding substances were removed with triethylammonium acetate. Binding substances were eluted stepwise with $25 \%$ acetonitrile (ACN), in water at a flow rate of $1.0 \mathrm{ml} \mathrm{min}{ }^{-1}$. Unless specified the chromatographic eluent was monitored at $254 \mathrm{~nm}$ using a (make and model of detector). The eluate was retained and frozen at $-80^{\circ} \mathrm{C}$ and lyophilised.

The eluate of the preparative reversed-phase chromatography column was purified further with affinity chromatography. The affinity chromatography gel, phenyl boronic acid coupled to a cation exchange resin (Biorex 70, Bio-Rad, USA), was synthesized according to Barnes et al.[20]. The affinity resin was packed into a glass column and equilibrated with $0.3 \mathrm{~mol} \mathrm{~L}^{-1}$ ammonium acetate ( $\mathrm{pH}$ 9.5). The $\mathrm{pH}$ of the eluate from the preparative reversedphase chromatography was adjusted to $\mathrm{pH} 9.5$ and loaded to the affinity column. The column was washed with an ammonium

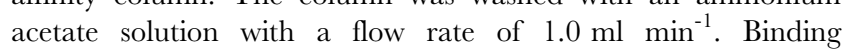


substances were eluted with $1 \mathrm{mmol} \mathrm{L}{ }^{-1} \mathrm{HCl}$ solution. The eluate was retained and frozen at $-20^{\circ} \mathrm{C}$.

$1 \mathrm{~mol} \mathrm{~L}^{-1}$ triethylammonium acetate was added to the eluate of the affinity chromatography (final concentration: $40 \mathrm{mmol} \mathrm{L}^{-1}$ ). The eluate of the affinity chromatography was injected into a reversed phase high performance liquid chromatography (Chromolith RP-18e 100-4.6, Merck, Germany) for desalting. After removal of substances not binding to the column with aqueous $40 \mathrm{mmol} \mathrm{L}^{-1}$ triethylammonium acetate, the absorbed substances were eluted with $20 \%$ acetonitrile (ACN) in water at a flow rate of $1.0 \mathrm{ml} \mathrm{min}{ }^{-1}$. Each eluate was frozen at $-80^{\circ} \mathrm{C}$ and lyophilized.

The lyophilised eluate was then dissolved in $40 \mathrm{mmol} \mathrm{L}^{-1}$ triethylammonium acetate (eluent $\mathrm{A}$ ) and injected in two reversed phase columns (Chromolith RP-18e 100-4.6 Merck, Germany) connected in series. $80 \%$ acetonitrile (eluent B) and the following gradient were used for the elution: 0-10\% B $40 \mathrm{~min}, 10-100 \% \mathrm{~B}$ $1 \mathrm{~min}, 100 \% \mathrm{~B} 2 \mathrm{~min}$. The flow rate was $1.0 \mathrm{ml} \mathrm{min}^{-1}$ and $1 \mathrm{ml}$ fractions were collected.

\section{Determination of Recovery Rates}

To calculate the recovery rate for $\mathrm{Up}_{4} \mathrm{U}$, in a control experiment, either culture medium or plasma $(40 \mathrm{ml})$ was spiked with $\mathrm{Up}_{4} \mathrm{U}(5 \mu \mathrm{g})$. These samples were fractionated as described above.

\section{Matrix Assisted Laser Desorption/Ionisation Mass Spectrometry (Maldi-MS)}

The lyophilised fractions of the reverse-phase chromatography were analysed by matrix-assisted laser desorption/ionisation mass spectrometry (MALDI-MS) and MALDI fragment ion analysis using a Bruker Ultraflex TOF/TOF instrument (Bruker-Daltonics, Germany). The concentrations of the analysed substances were $1-10 \mu \mathrm{mol} \mathrm{L}{ }^{-1}$ in double distilled water. $1 \mu \mathrm{l}$ of the analyte solution was mixed with $1 \mu \mathrm{l}$ of matrix solution $\left(50 \mathrm{mg} \mathrm{ml}^{-1} 3\right.$ hydroxy-picolinic acid in water). Cation exchange beads (AG $50 \mathrm{~W}-\mathrm{X} 12,200-400$ mesh, Bio-Rad, Germany) were added to this mixture and equilibrated with $\mathrm{NH}_{4}{ }^{+}$as a counter-ion to remove $\mathrm{Na}^{+}$and $\mathrm{K}^{+}$ions. $1 \mu \mathrm{l}$ of each fraction was prepared on a prestructured MALDI sample support (MTP AnchorChip ${ }^{\text {TM }}$ 400/384, Bruker-Daltonics, Germany) [21] and dried gently on an inert metal surface before introduction into the mass spectrometer.

Mass-spectrometric measurements were performed on a Bruker Ultraflex-III TOF/TOF instrument (Bruker-Daltonics, Germany). The instrument was equipped with a Smart beam ${ }^{\mathrm{TM}}$ laser operating with a repetition-rate of 100-200 Hz. On average, the presented spectra are the sums of 300 single-shot spectra for MS mode, and 1,000 for MS/MS mode. Argon was used as collisioninduced dissociation (CID) gas. Mass spectra of positively charged ions were analysed in the reflector mode using delayed ion extraction. Fragment ion spectra were recorded using the LIFT option of the instrument. The calibration constants were determined using standard peptides prepared on positions adjacent to the sample, resulting in an error of $<50 \mathrm{ppm}$ for the recorded mass spectra. The dinucleoside polyphosphate ApcpcpA was added to the sample as internal standard in the case of kinetic measurements by using MALDI mass spectrometry. Local differences in the $\mathrm{Up}_{4} \mathrm{U}$-concentration on the MALDI spot were thereby eliminated [22].

\section{Enzymatic Cleavage Experiments}

Enzymatic cleavage experiments were performed as described elsewhere [16,23]. Briefly, 5-nucleotide hydrolase (3 mU) from
Crotalus durissus (Sigma-Aldrich, Germany), 3̀-nucleotide hydrolase $(1 \mathrm{mU})$ from calf spleen (Sigma-Aldrich, Germany) and alkaline phosphatase $(1 \mathrm{mU})$ from calf intestinal mucosa (Fluka, Germany), respectively were mixed with $50 \mu \mathrm{l} \mathrm{NaHCO}_{3}$ and activated CNBr-Sepharose $6 \mathrm{MB}$ beads (Amersham-Pharmacia Biotech, Sweden). The mixture was incubated for 2 hours at room temperature. After incubation, the beads were washed 3 times with double distilled water. Aliquots of the fractions from the reversed phase chromatography were incubated with these enzyme-beads for 2 hours at room temperature. Aliquots of the reaction mixture were examined by MALDI-MS. 40-50 single spectra were accumulated to improve the signal-to-noise ratio [23]. Sample preparation and measurements were done at the same conditions as for the original samples.

\section{Synthesis of Diuridine $\left(5^{\prime}, 5^{\prime}\right)$ Tetraphosphate}

$\mathrm{Up}_{4} \mathrm{U}$ was synthesized according to $\mathrm{Ng}$ and Orgel [24]. Uridine 5 '-diphosphate (UDP; $\left.50 \mathrm{mmol} \mathrm{L}{ }^{-1}\right),(\mathrm{N}$-[2-hydroxyethyl]-piperazine-N-[2-ethanesulfonic acid]) (HEPES; $2 \mathrm{~mol} \mathrm{~L}^{-1}$, 1-ethyl-3-(3dimethylamino-propyl)carbodiimide $\left(2.5 \mathrm{~mol} \mathrm{~L}^{-1}\right)$ and magnesium chloride $\left(\mathrm{MgCl}_{2} ; 125 \mathrm{mmol} \mathrm{\textrm {L } ^ { - 1 } )}\right.$ were dissolved in water, thoroughly mixed with a vortex mixer and incubated at $37^{\circ} \mathrm{C}$ at pH 6.5 for 48 h. Purification of chemically synthesized dinucleoside $\left(5^{\prime}, 5^{\prime}\right)$ polyphosphates was performed as described elsewhere [25]. Briefly, the synthesized dinucleoside polyphosphates were concentrated on a C18 reversed phase column (LiChroprep, $310 \times 25 \mathrm{~mm}, 65-40 \mu \mathrm{m}$, Merck, Darmstadt, Germany) using $40 \mathrm{mmol} \mathrm{L}^{-1}$ aqueous triethylammonium acetate (TEAA) in water

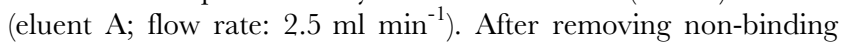
substances with eluent $\mathrm{A}$ (flow rate: $2.5 \mathrm{ml} \mathrm{min}^{-1}$ ), nucleotides were eluted with $36 \%$ acetonitrile in water (eluent B; flow rate: $2 \mathrm{ml}$ $\left.\mathrm{min}^{-1}\right)$. The eluate was lyophilized and stored frozen at $-80^{\circ} \mathrm{C}$. The lyophilized eluate of the preparative reversed phase chromatography was dissolved in aqueous $40 \mathrm{mmol} \mathrm{L}^{-1}$ triethylammonium acetate solution and injected on two C18 reversed phase columns connected in series (Supersphere, $300 \times 8 \mathrm{~mm}, 4 \mu \mathrm{m}$, Merck, Germany) which were equilibrated with aqueous $40 \mathrm{mmol}$ $\mathrm{L}^{-1}$ triethylammonium acetate (carrier). The carrier was pumped through the system with a flow rate of $100 \mu \mathrm{l} \mathrm{min}^{-1}$ during injection of the sample. After the injection was finished, n-butanol $\left(160 \mathrm{mmol} \mathrm{L}^{-1}\right)$ in $40 \mathrm{mmol} \mathrm{L}^{-1}$ triethylammonium acetate was used as displacer (flow rate: $200 \mu \mathrm{min}^{-1}$ ). The fraction size was $1.9 \mathrm{ml}$. Each fraction of the displacement-chromatography possibly containing dinucleoside polyphosphates was lyophilized, dissolved in $1 \mathrm{ml} 20 \mathrm{mmol} \mathrm{L}^{-1} \mathrm{~K}_{2} \mathrm{HPO}_{4}$ in water, pH 8, (eluent A) and chromatographed by using an anion-exchanger (column: UNO Q-12, BioRad, Germany)(eluent B: $20 \mathrm{mmol} \mathrm{L}^{-1} \mathrm{~K}_{2} \mathrm{HPO}_{4}$ and $1 \mathrm{~mol} \mathrm{~L}^{-1}$ salt $(\mathrm{pH} 8)$ in water; gradient: $0-10 \mathrm{~min}$ : $0-5 \% \mathrm{~B}$; 10-10 min: 5-35\% B; 100-101 min: 35-100\% B; flow rate:

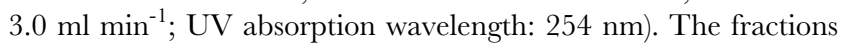
of the anion-exchange chromatography were desalted by HPLC reversed phase $\mathrm{C} 18$ chromatography. The reversed phase column (Chromolith $^{\text {TM }}$ Performance RP-18e100-4.6, Merck, Germany) was equilibrated with eluent A $\left(40 \mathrm{mmol} \mathrm{L}^{-1}\right.$ triethylammonium acetate). Each sample dissolved in $40 \mathrm{mmol} \mathrm{L}^{-1}$ triethylammonium acetate was pumped with a flow rate of $1.0 \mathrm{ml} \mathrm{min}^{-1}$ onto the column. After 20 minutes washing the column with $30 \mathrm{ml}$ eluent A, the substances were eluted with $32 \%$ acetonitrile in water (eluent B). The resulting fractions were lyophilized and stored at $-80^{\circ} \mathrm{C}$. The lyophilized fractions from the HPLC reversed phase C18 chromatography were examined by MALDI-MS. 


\section{Isolation and Identification of Diuridine Tetraphosphate in Human Plasma}

The blood collection was approved by the ethical committee of the Charité. The probands gave their written consent. Peripheral blood $(20 \mathrm{ml})$ was drawn from the cubital vein in six healthy subjects and was collected in tubes containing $\mathrm{K}_{2}$-EDTA $(7.2 \mathrm{mg})$. The mean age of the subjects (m/f: $3 / 3$ ) was $31.8 \pm 2.8$, systolic blood pressure $118 \pm 2(\mathrm{mmHg})$, diastolic blood pressure $73 \pm 3$ $(\mathrm{mmHg})($ each mean $\pm \mathrm{SEM})$. The blood samples were centrifuged at $2,100 \mathrm{~g}$ for $10 \mathrm{~min}$ at $4^{\circ} \mathrm{C}$ for isolation of plasma, after a standardized interval of $15 \mathrm{~min}$ post sampling. $5 \mu \mathrm{g}$ of a diinosine tetraphosphate $\left(\mathrm{Ip}_{4} \mathrm{I}\right)$ was added as internal standard and used to compensate for any losses during purification. The plasma was deproteinized with $0.6 \mathrm{~mol} \mathrm{~L} \mathrm{~L}^{-1}$ (final concentration) perchloric acid and centrifuged $\left(2,100 \mathrm{~g}, 4^{\circ} \mathrm{C}, 5 \mathrm{~min}\right)$. After adjusting $\mathrm{pH}$ to 7.0 with $5 \mathrm{~mol} \mathrm{~L}^{-1} \mathrm{KOH}$ the precipitated proteins and $\mathrm{KClO}_{4}$ were removed by centrifugation $\left(2,100 \mathrm{~g}, 4^{\circ} \mathrm{C}, 5 \mathrm{~min}\right)$.

\section{Isolation and Identification of Diuridine Tetraphosphate from Human Plasma}

Triethylammonium acetate (TEAA) in water was added to the deproteinized plasma to a final concentration of $40 \mathrm{mmol} \mathrm{L}^{-1}$. This mixture was fractionated to homogeneity by reversed phase chromatographic and affinity chromatographic methods comparable to the methods used for the chromatographic analysis of the endothelial secretome. $\mathrm{Up}_{4} \mathrm{U}$ was identified on the basis of its retention time as compared to synthetic $\mathrm{Up}_{4} \mathrm{U}$. The lyophilised fractions from the reverse phase HPLC with TEAA as the ion-pair reagent were further separated by analytic reverse phase HPLC using tetrabutylammonium hydrogensulfate (TBA) as the ion-pair reagent. The fractions, dissolved in $150 \mu \mathrm{l}$ of $2 \mathrm{mmol} \mathrm{L}^{-1} \mathrm{TBA}$ and $10 \mathrm{mmol} \mathrm{L}^{-1} \mathrm{~K}_{2} \mathrm{HPO}_{4}(\mathrm{pH}$ 6.5), were injected into a reverse phase HPLC column (Chromolith ${ }^{\text {TM }}$ Performance, RP-18e; 100$4.6 \mathrm{~mm}$; Merck, Germany). Acetonitrile $(80 \%$ (v/v) in water: eluent B) and the following gradient was used for the elution: 041 min: $0-30 \%$ eluent $\mathrm{B}$; 41-41.5 min: $30-100 \%$ eluent $\mathrm{B}$; $41.5-$ $44.5 \mathrm{~min}$ : $100 \%$ eluent $\mathrm{B}$; flow: $3 \mathrm{ml} \mathrm{min}^{-1}$. The concentrations of $\mathrm{Up}_{4} \mathrm{U}$ were calculated using calibration curves created with synthetic $\mathrm{Up}_{4} \mathrm{U}$.

\section{Detection of Endothelial Cell Proliferation}

To detect cell proliferation after treatment with $\mathrm{Up}_{4} \mathrm{U}$, HUVECs were incubated in the presence of $10 \mu \mathrm{mol} \mathrm{L}^{-1}$ of the thymidine analogue 5 'bromo-2'deoxyuridine, following the manufacturer's protocol (BrdU, Roche, Germany). Briefly, HUVEC were seeded into 96 well plates at a cell density of 2,000 cells well ${ }^{-1}$. Cells were treated with increasing concentrations of $\mathrm{Up}_{4} \mathrm{U}(0,0.1$, $\left.1,10,100 \mathrm{nmol} \mathrm{L}^{-1}\right)$ in endothelial cell growth medium containing $0.1 \% \mathrm{FBS}$ for $24 \mathrm{~h}$. To inhibit the $\mathrm{Up}_{4} \mathrm{U}$ effect, cells were treated with $100 \mu \mathrm{mol} \mathrm{L}{ }^{-1}$ suramin (Sigma-Aldrich, Germany) in the presence of $\mathrm{Up}_{4} \mathrm{U}$. Cells were labelled with $10 \mu \mathrm{mol} \mathrm{L^{-1 }} \mathrm{BrdU}$ in the last $4 \mathrm{~h}$ of treatment. After fixation, cells were incubated with Blocking Reagent (Roche, Germany) for $30 \mathrm{~min}$ to reduce unspecific binding of the antibody conjugate. Incorporated $\mathrm{BrdU}$ was detected with monoclonal anti-BrdU-POD antibody (30 min at RT) and ABST substrate (15-30 min at RT). Absorbance was measured at $370 \mathrm{~nm}$ (reference $492 \mathrm{~nm}$ ). The experiment was carried out with 6 wells for each treatment and was repeated three times.

\section{Migration Assays}

Migration assays were performed using a disposable 96-well ChemoTX chamber (Neuro Probe, USA) with $8 \mu \mathrm{m}$ pores. Prior to each experiment filters were coated with $0.1 \mathrm{mg} \mathrm{ml}^{-1}$ collagen type $\mathrm{I}$ and placed at $37^{\circ} \mathrm{C}$ for $1 \mathrm{~h}$ to polymerize. For each experiment quiescent cells were loaded with $1 \mu \mathrm{mol} \mathrm{L}{ }^{-1}$ CalceinAM (Invitrogen, USA) in DMEM containing 0\% FCS and $1.25 \mathrm{mmol} \mathrm{\textrm {L } ^ { - 1 }}$ probenecid for $1 \mathrm{~h}$ to enable a fluorescent detection of the cells. After loading with the dye cells were harvested with trypsin and resuspended in DMEM containing $0 \%$ FCS and $1.25 \mathrm{mmol} \mathrm{L}^{-1}$ Probenecid. The lower wells of the plate were filled with test substances, covered with the filter and $2.5 \times 10^{4}$ cells were placed on the filter sites. The chamber was incubated for $5 \mathrm{~h}$ at $37^{\circ} \mathrm{C}$ and $5 \% \mathrm{CO}_{2}$. Following incubation, non-migrated cells were mechanically removed and the filter was measured using the fluorescence signal of calcein at $485 \mathrm{~nm}$ (excitation) and $535 \mathrm{~nm}$ (emission) in a fluorescence plate reader (Mithras LB 940, Berthold Technologies, Germany).

\section{Detection of Vascular Smooth Muscle Cell Proliferation}

Proliferation was determined by bromodeoxyuridine (BrdU) incorporation during DNA synthesis, using a BrdU-ELISA (Roche Diagnostics, Switzerland). Cells were plated at a density of 2,500 cells well ${ }^{-1}$ in 96 -well plates and cultured for $24 \mathrm{~h}$. Following $24 \mathrm{~h}$ in serum-reduced medium $(0.5 \%$ FCS $)$, the culture medium was removed and fresh medium containing the test substances was added to the growth-arrested cells for another $24 \mathrm{~h}$. BrdU was offered in the last $4 \mathrm{~h}$ of the incubation time. After stimulation cells were fixed, incubated with anti-BrdU-POD antibody and washed according to manufacturers instructions. Substrate solution was added to the wells and the luminescence signal representing the BrdU incorporation was recorded immediately by a luminescence plate reader (Mithras LB 940, Berthold Technologies, Germany).

\section{Tube Formation}

The tube formation assay was carried out with the $\mu$-slide angiogenesis system from Ibidi (Integrated BioDiagnostics, Germany). The $\mu$-slides were coated with growth-factor reduced $\mathrm{BD}$ Matrigel (BD Biosciences, Japan) and placed at $37^{\circ} \mathrm{C}$ for $1 \mathrm{~h}$ to polymerize. HMECs were harvested and resuspended in growth

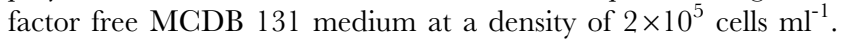
From this solution $50 \mu \mathrm{l}$ were applied in each $\mu$ l-slide well and incubated for $6 \mathrm{~h}$. Tube formation was measured using microscopic images of five different areas. Tubular length and total number of tubes were quantified.

\section{Sheroid Sprouting Assay}

HUVEC cells were cultured in endothelial cell culture medium consisting of endothelial basal cell growth medium containing (ECM2), 2\% FBS and endothelial cell growth supplements. The cells were cultured to $90 \%$ confluency at $37^{\circ} \mathrm{C}$ and $5 \% \mathrm{CO}_{2}$ and used from passage 2 to passage 4 . Endothelial spheroids were generated as described previously [26]. Briefly, human umbilical vein endothelial cells $(2,500-3,000$ cells per spheroid) were resuspended in endothelial cell culture medium containing $20 \%$ carboxymethylcellulose and plated in nonadherent round-bottom 96-well plates for 24 hours allowing single spheroid aggregation. Spheroids were harvested and combined in a $1.5 \mathrm{ml}$ Eppendorf tube. Cell culture supernatant was removed after centrifugation for $1 \mathrm{~min}$ at $500 \mathrm{x}$ g. 30 spheroids were embedded into $120 \mu \mathrm{l}$ collagen gels in 24-well plates [27]. For collagen stock solution, 8 vol rat tail collagen type I (Collaborative Medical Products, US) was mixed with 1 vol. 10x PBS (Sigma-Aldrich, Germany) and 1 vol. $0.1 \mathrm{~N} \mathrm{NaOH}$ to adjust to $\mathrm{pH} 7.4$ at room temperature. This stock solution was then mixed with an equal volume of endothelial basal growth medium (ECM2, Lonza, Germany) containing 40\% FBS (Lonza, Germany) and 0.5\% carboxymeth- 
ylcellulose to prevent spheroid sedimentation during collagen gel polymerization. Spheroid containing gels were allowed to polymerize for $20 \mathrm{~min}$ at $37^{\circ} \mathrm{C}$ and $5 \% \mathrm{CO}_{2}$ and then overlaid with endothelial cell culture medium (ECM), supplemented with Up4U concentrations as indicated or $20 \mathrm{ng} \mathrm{ml}^{-1}$ VEGF (Sigma-Aldrich, Germany). After 24 hours in vitro sprout formation was evaluated in phase-contrast images (Leica, Germany) and quantified by SCORE image analysis (SCO Life Science, Germany).

\section{Phosphoprotein Detection for Map-Kinases}

Serum-starved VSMCs were stimulated with $\mathrm{Up}_{4} \mathrm{U}$ for the indicated time points. After harvesting cells with ice-cold cell lysis buffer (Biorad, Munich, Germany), centrifuged for $20 \mathrm{~min}$ at $4^{\circ} \mathrm{C}$ and $13.000 \mathrm{rpm}$, supernatant was spiked with equal amount of assay buffer (Biorad, Munich, Germany). Protein amount of the lysates was determined with $\mathrm{BCA}^{\mathrm{TM}}$ assay kit (Pierce, Rockford, USA). Determination of phosphorylated as well as total protein was assayed using Luminex ${ }^{\text {TM }}$ technology with the phosphoprotein detection assay (Biorad, Munich, Germany).

\section{In-Vivo/Ex-Vivo Assay of Up4U Production in Isolated Aortic Rings}

Thoracic and abdominal aorta was isolated from Wistar rats $(n=4)$. The surrounding fat tissue was removed and aortas were serially cross-sectioned into $1-2 \mathrm{~mm}$ rings. A total of $10-15$ aortic rings were seeded into a 12-well plate and serum-starved in OptiMEM for $24 \mathrm{~h}$ to equilibrate their growth factor responses. Then the conditioned medium was collected (base-line) and fresh serumfree medium was added in the absence (Control) or presence of calcium ionophore $\left(10 \mu \mathrm{mol} \mathrm{L}{ }^{-1}\right.$, Sigma) or endothelin $1(0.1 \mathrm{nmol}$ $\mathrm{L}^{-1}$, Sigma). Conditioned media was collected after 45 minutes, deproteinated and frozen until assayed.

\section{Statistical Methods}

Data are given as mean values with standard error mean (SEM). All statistical analyses were done using SPSS software (Microsoft SPSS for Windows, version 12.0). The Wilcoxon-Mann-Whitney test was used for non-parametric statistical tests. $\mathrm{p}<0.05$ (twosided) was considered to indicate statistical significance.

\section{Results}

The screening approach using the chorioallantoic membrane of the developing rat embryo [11,28] showed that the supernatant obtained from HMEC-1 stimulated by shear stress elicited an angiogenic effect in comparison to control (Figure 1.A). Gestational day 9.5 rat embryos were cultured for $48 \mathrm{~h}$. This time period during embryogenesis covers a major part of organogenesis, when a complex vasculature is developed in the yolk sac as well as in the embryo itself. The most prominent blood vessels are located in the yolk sac surrounding the embryo. In the negative control cultivated with HBSS and bovine serum (Figure 1.A.I), the yolk sac exhibited an immature vascular network consisting of irregularly organised small vessels. The corresponding vascular system is developed by angiogenic factors like VEGF as positive control (Figure 1.A.II). By contrast, the primitive placenta and yolk sac of the embryos exposed to the secretome of endothelial cells showed a highly organized vasculature containing large and small vessels (Figure 1.A.III). Furthermore, the supernatant from endothelial cells were treated with immobilised alkaline phosphatase, which metabolises mono- but not dinucleoside polyphosphates. Incubation with the immobilised alkaline phosphatase had a slightly diminished effect on angiogenesis (Figure 1.A.IV). This
A

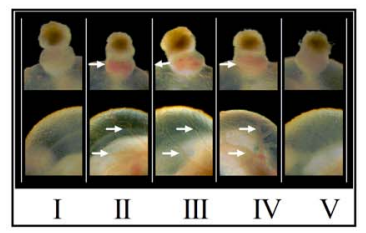

$\mathrm{C}$
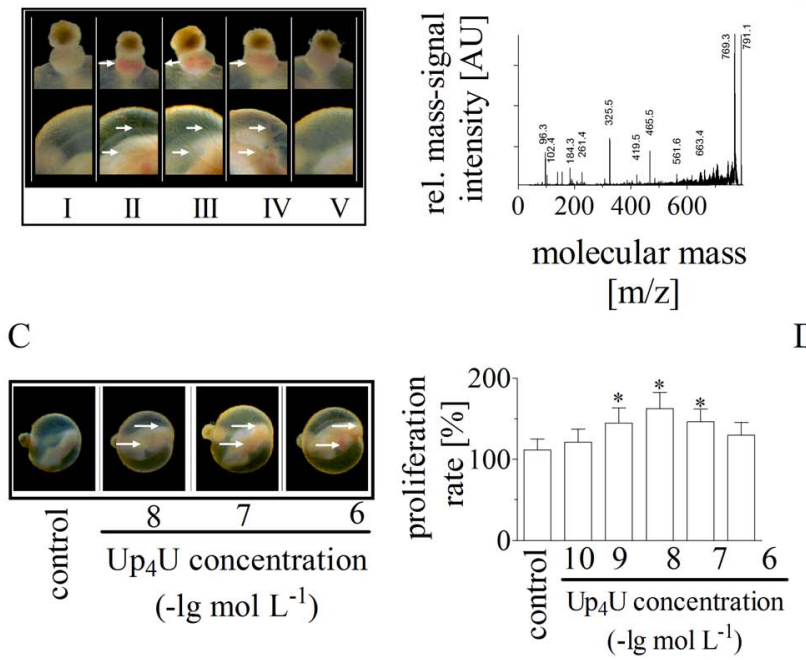

$\mathrm{E}$
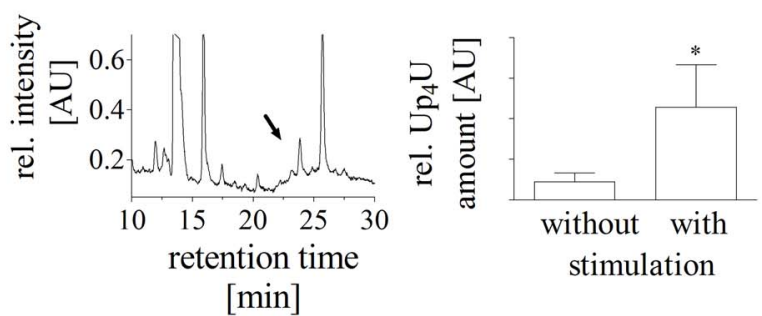

stimulation

Figure 1. (A) Angiogenic effects of endothelial secretome in the rat embryo chorioallantoic membrane. The primitive placenta and yolk sac of rat embryos cultured during organogenesis under negative control conditions (HBSS and bovine serum) (I). The corresponding vascular system is underdeveloped and could be improved by angiogenic factors like VEGF as positive control (II). More complex and structured blood vessels and red staining caused by red blood cells in the blood vessels (marked by arrows). Morphologic evaluation of angiogenic effect of the endothelial secretome (III), of the endothelial secretome after incubation with alkaline phosphate (IV), and of the endothelial secretome after incubation with alkaline phosphate in the presence of suramin (V). (B) MALDI-TOF-TOF mass spectrum of the fraction from the analytical reversed-phase chromatography. (C) Enhanced vascularisation of rat embryonic yolk sac membranes induced by increasing $\mathrm{Up}_{4} \mathrm{U}$ concentrations after $48 \mathrm{~h}$ of culture. Typical result out of 5 similar experiments. (D) Effect of increasing $U_{4} U$ concentration on proliferation rate of human endothelial cells $(n=7)$. (E) Reversed phase chromatography of the fraction of human plasma containing the remaining nucleotides after exclusion of mononucleotides. $(\mathbf{F}) \cup \mathrm{p}_{4} U$ release of cultivated endothelial cells after stimulation by a cone-andplate viscometer with shear stress of $3 \mathrm{~N} \mathrm{~m}^{-2}(n=11)$. doi:10.1371/journal.pone.0068575.g001

effect was abolished in the presence of the unspecific $\mathrm{P}_{2}$-receptor antagonist suramin (Figure 1.A.V).

These experiments helped to choose the additional purification steps applied to endothelial cell supernatants. First, we deproteinized supernatants from stimulated endothelial cells to isolate fractions most likely containing endothelial-derived nucleotides. After deproteination, we desalted the supernatants by using a preparative reversed-phase chromatography chromatography (Figure S1.A.). The $30 \%$ acetonitrile eluates of the reversed phase chromatography were fractionated by using a phenylboronate affinity column in order to separate mononucleotides from nucleotides containing at least two pairs of neighbouring cis-diol 
groups (Figure S1.B.). Afterwards, we fractionated the nucleotides containing at least two pairs of neighbouring cis-diol groups by analytical reversed-phase chromatography. The resulting chromatogram showed a single sharp UV peak (Figure S1.C.).

The MALDI-TOF-TOF mass spectrum obtained from the underlying fraction revealed a molecular mass of $791.4 \mathrm{Da}$ $\left(\mathrm{M}+\mathrm{H}^{+}\right)$. Figure 1.B demonstrates the MALDI-TOF-TOF-MS/ MS-LIFT-fragmentation mass-spectrum of the underlying substance. Each mass-fragments signal was attributable to a fragment of $\mathrm{Up}_{4} \mathrm{U}$ by using an in-house database and was identical with the MS/MS fragmentation mass-spectrum of synthetic $\mathrm{Up}_{4} \mathrm{U}$ as shown in Table 1, suggesting that $\mathrm{Up}_{4} \mathrm{U}$ was the substance under investigation. Molecular structure of $\mathrm{Up}_{4} \mathrm{U}$ is given in

\section{Figure S1.D.}

After identification and synthesis of $\mathrm{Up}_{4} \mathrm{U}$, the angiogenic effects of synthetic $\mathrm{Up}_{4} \mathrm{U}$ were verified using the assay whole embryo culture system $[11,28]$. Figure 1.G demonstrates the impact of $\mathrm{Up}_{4} \mathrm{U}$ on the morphological pattern of the vascularisation of the yolk sac membrane. In the negative control, the yolk sac exhibited an immature vascular network consisting of irregular organised small vessels. By contrast, the yolk sac of the embryos exposed to the $\mathrm{Up}_{4} \mathrm{U}$ showed a highly organized vasculature containing large and small vessels (Figure 1.C).

Since proliferation of endothelial cells is essential for angiogenesis, next, the effect of $\mathrm{Up}_{4} \mathrm{U}$ on the proliferation rate of endothelial cells was analysed. $\mathrm{Up}_{4} \mathrm{U}$ induced a strong concentration-dependent stimulation of the proliferation of human endothelial cells at low concentrations; the proliferative effect of $\mathrm{Up}_{4} \mathrm{U}$ is inhibited by a feedback mechanism at concentrations above
$10^{-7} \mathrm{~mol} \mathrm{~L}^{-1}$ (Figure 1.D). The threshold effect of $\mathrm{Up}_{4} \mathrm{U}$ was obtained at a concentration of $1 \mathrm{nmol} \mathrm{L}^{-1}$.

To investigate whether $\mathrm{Up}_{4} \mathrm{U}$ plasma concentrations are sufficient to induced angiogenesis, we quantified $\mathrm{Up}_{4} \mathrm{U}$ plasma concentration in healthy subjects by reversed-phase chromatography (Figure 1.E). The mean age of the subjects (m/f: $3 / 3$ ) was $31.8 \pm 2.8$, systolic blood pressure $118 \pm 2(\mathrm{mmHg})$, diastolic blood pressure $73 \pm 3(\mathrm{mmHg})($ each mean $\pm \mathrm{SEM})$. The mean $( \pm \mathrm{SEM})$ peripheral venous plasma $\mathrm{Up}_{4} \mathrm{U}$ concentration was $1.34 \pm 0.26 \mathrm{nmol} \mathrm{L}^{-1}(\mathrm{~N}=6)$.

Afterwards, we studied endothelial $\mathrm{Up}_{4} \mathrm{U}$ release under physiologic conditions using a cone-and-plate viscometer. Shear stress of $3 \mathrm{~N} \mathrm{~m}^{-2}$ for $24 \mathrm{~h}$ caused a strong increase in $\mathrm{Up}_{4} \mathrm{U}$ concentration in the endothelial secretome compared to control situation without shear stress application (Figure 1.F).

To investigate whether $\mathrm{Up}_{4} \mathrm{U}$ not only increases the proliferation rate of endothelial cells, but also effects growth of vascular smooth muscle cells (VSMC), next the effect of $\mathrm{Up}_{4} \mathrm{U}$ on the VSMC proliferation rate was tested in the presence and absence of platelet-derived growth factor (PDGF). While $\mathrm{Up}_{4} \mathrm{U}$ had no direct effect on the VSMC proliferation rate at concentration below $10 \mu \mathrm{mol} \mathrm{L} \mathrm{L}^{-1}$ (Figure 2.A), $\mathrm{Up}_{4} \mathrm{U}$ strongly increased VSMC proliferation rate in the presence of PDGF at low concentration range (Figure 2.B). $\mathrm{Up}_{4} \mathrm{U}$, but not its metabolites, UTP and UDP, caused this increasing effect, since UTP (Figure 2.G) and UDP (Figure 2.D) had no effect on the VSMC proliferation rate in the presence of PDGF. In the next step, we investigated potential receptors involved. Suramin significantly inhibited $\mathrm{Up}_{4} \mathrm{U}$ induced proliferation whereas PPADS, RBII and MRS2179 had

Table 1. Molecular masses of Up 4 U fragments obtained by MALDI-TOF-TOF mass spectrometry (Figure 1.B).

\begin{tabular}{|c|c|c|c|c|}
\hline $\begin{array}{l}\text { Fragment ions } \\
{[\mathrm{M}+\mathrm{H}]^{+}}\end{array}$ & $\begin{array}{l}\mathrm{Up}_{4} \mathrm{U} \text { isolated from } \\
\text { endothelial secretome } \\
\text { (measured) }\end{array}$ & $\begin{array}{l}U p_{4} \mathrm{U} \text { isolated from } \\
\text { plasma (measured) }\end{array}$ & $\begin{array}{l}\text { Up } \mathrm{p}_{4} \mathrm{U} \text { fragment } \\
\text { mass (calculated) }\end{array}$ & $\begin{array}{l}\text { synthetic } \mathrm{Up}_{4} \mathrm{U} \\
\text { (measured) }\end{array}$ \\
\hline U-NH & 96.3 & & 96.0 & 96.0 \\
\hline $\mathrm{C}_{4} \mathrm{H}_{6} \mathrm{O}_{3}$ & 102.4 & 101.8 & 102.0 & 102.1 \\
\hline $\mathrm{U}+\mathrm{CHO}$ & 140.4 & 140.7 & 140.0 & 140.0 \\
\hline $\mathrm{C}_{5} \mathrm{H}_{12} \mathrm{O}_{5} \mathrm{P}$ & 184.3 & 184.6 & 183.0 & 184.1 \\
\hline U & 245.3 & 243.7 & 243.1 & 244.0 \\
\hline $\mathrm{U}+\mathrm{H}_{2} \mathrm{O}$ & 261.4 & 261.6 & 261.1 & 261.4 \\
\hline $\mathrm{U}-2 \mathrm{H}_{2} \mathrm{O}$ & 207.3 & 207.4 & 207.1 & 207.0 \\
\hline$U p_{1}$ & 325.5 & 324.3 & 323.0 & 325.1 \\
\hline $\mathrm{Up}_{2}-\mathrm{H}_{2} \mathrm{O}$ & 384.3 & 385.9 & 384.9 & 385.0 \\
\hline$U p_{2}$ & 402.9 & 403.1 & 402.9 & 403.1 \\
\hline $\mathrm{Up}_{2}+\mathrm{H}_{2} \mathrm{O}$ & 419.5 & 419.1 & 420.9 & 421.1 \\
\hline $\mathrm{Up}_{3}-\mathrm{H}_{2} \mathrm{O}$ & 465.5 & 465.9 & 464.9 & 467.0 \\
\hline$U p_{3}$ & 483.5 & 484.0 & 482.9 & 484.0 \\
\hline $\mathrm{Up}_{4}$ & 561.6 & 567.3 & 562.9 & 563.0 \\
\hline M- Up $p_{4}$ & 229.3 & 228.4 & 227.1 & 227.0 \\
\hline $\mathrm{M}-\mathrm{U}-\mathrm{H}_{2} \mathrm{O}$ & 663.4 & 660.9 & 660.9 & 661.2 \\
\hline $\mathrm{M}-\mathrm{H}_{2} \mathrm{O}$ & 773.1 & 773.3 & 772.3 & 773.5 \\
\hline $\mathrm{M}-\mathrm{H}_{2} \mathrm{O}-2 \mathrm{H}$ & 769.3 & 769.4 & 769.9 & 768.5 \\
\hline$M$ & 791.1 & 791.0 & 791.3 & 791.4 \\
\hline
\end{tabular}

The first column shows the fragment masses measured by MALDI-TOF-TOF mass spectrometry; second column shows the fragments mass of Up $\mathrm{p}_{4} \mathrm{U}$ isolated from the endothelial secretome; the third column the fragments mass of $\mathrm{Up}_{4} \mathrm{U}$ isolated from plasma; the fourth column shows the fragment masses calculated from their respective structures; the fifth column shows the fragments masses of synthesised $\mathrm{Up}_{4} \mathrm{U} . \mathrm{M}^{+}=$protonated parent ion; $\mathrm{U}=$ uracil; $\mathrm{U}=$ uridine; $\mathrm{p}=$ phosphate group, e.g. $\mathrm{Up}_{3}=\mathrm{UTP} ; \mathrm{w} / \mathrm{o}=$ without.

doi:10.1371/journal.pone.0068575.t001 

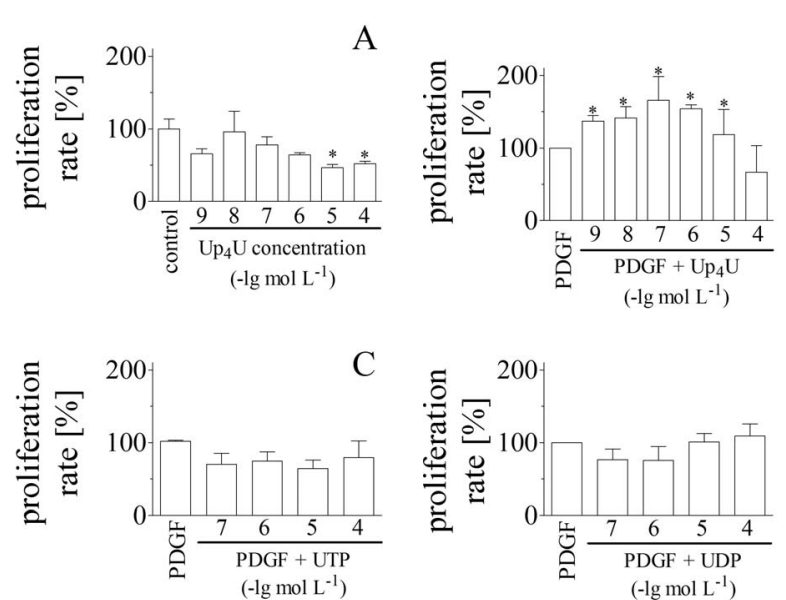

$\mathrm{D}$

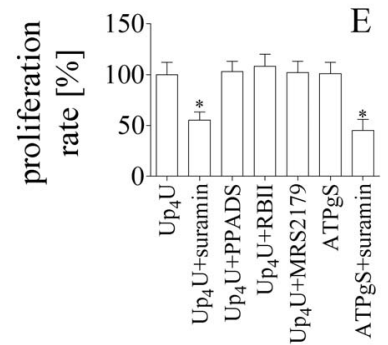

Figure 2. (A)Effect of increasing $U p_{4} U$ concentrations on proliferation rate of vascular smooth muscle cells in the absence of PDGF $(n=6)$. (B)Effect of increasing $\mathrm{Up}_{4} \mathrm{U}$ concentrations on proliferation rate of vascular smooth muscle cells in the presence of PDGF $\left(10^{-6} \mathrm{~mol} \mathrm{~L}^{-1}\right.$ PDGF each; $n=3$ ). (C)Effect of increasing UTP concentrations on proliferation rate of vascular smooth muscle cells in the presence of PDGF $\left(10^{-6} \mathrm{~mol} \mathrm{~L}^{-1}\right.$ PDGF each; $\left.n=3\right)$. (D)Effect of increasing UDP concentrations on proliferation rate of vascular smooth muscle cells in the presence of PDGF $\left(10^{-6} \mathrm{~mol} \mathrm{~L}^{-1}\right.$ PDGF each; $\left.n=3\right)$. (E)Effect of $U p_{4} U$ $\left(10^{-7} \mathrm{~mol} \mathrm{~L}^{-1}\right)$ or ATP $\gamma S\left(10^{-7} \mathrm{~mol} \mathrm{~L}^{-1}\right)$ in the presence of PDGF $\left(10^{-6} \mathrm{~mol} \mathrm{~L}^{-1}\right.$ PDGF each; $\left.\mathrm{n}=3\right)$ and suramin $\left(10^{-4} \mathrm{~mol} \mathrm{~L}^{-1}\right)$, PPADS $\left(10^{-5} \mathrm{~mol} \mathrm{~L}^{-1}\right)$, MRS2179 $\left(10^{-5} \mathrm{~mol} \mathrm{~L}^{-1}\right)$ or RBII $\left(10^{-5} \mathrm{~mol} \mathrm{~L}^{-1}\right)$ on proliferation rate of vascular smooth muscle cells. doi:10.1371/journal.pone.0068575.g002

no effect. From the inhibitory pattern of these non-selective P2Yreceptor antagonists, we had the idea of the $\mathrm{P} 2 \mathrm{Y} 2$ receptor activated by $\mathrm{Up}_{4} \mathrm{U}$. The non-hydrolizable ATP- $\gamma \mathrm{S}$ is a selective agonist at the $\mathrm{P} 2 \mathrm{Y} 2$ receptor. $\mathrm{ATP} \gamma \mathrm{S}$ is also able to induce a potent proliferation which is in part inhibitable by suramin (Figure 2E).

Since migration of endothelial cells is essential for neovascularization as well as proliferation, the effect of $\mathrm{Up}_{4} \mathrm{U}$ on migration rate was then analysed. $\mathrm{Up}_{4} \mathrm{U}$ induced a concentration-dependent increase in the migration rate of endothelial cells (open bars of Figure 3.A), which was abolished in the presence of suramin, indicating the involvement of the P2Y2-receptors in this effect (filled bar of Figure 3A). The $\mathrm{Up}_{4} \mathrm{U}$ effect on migration rate was stronger than the effects of UTP (Figure 3.B) and ATP (Figure 3.G).

To investigate whether $\mathrm{Up}_{4} \mathrm{U}$ affects the ability of endothelial cells to form capillary-like tubes, endothelial cells were exposed to $\mathrm{Up}_{4} \mathrm{U}$ for $6 \mathrm{~h}$ and examined for tube formation microscopically. $\mathrm{Up}_{4} \mathrm{U}$ produced an increased number of tubes compared to control (Figure 3.D). The tube formation by $\mathrm{Up}_{4} \mathrm{U}$ was additive to that of PDGF (Figure 3.D). Characteristic microscopic images are given in Figure 3.E.
To further analyze the effects of $\mathrm{Up}_{4} \mathrm{U}$ on endothelial functions and responsiveness, we performed experiments in gel angiogenesis with EC spheroids. Spheroids were embedded in collagen gels and stimulated with $\mathrm{Up}_{4} \mathrm{U}$ or VEGF as positive control. The cumulative length of outgrowing capillary-like sprouts was quantified after $24 \mathrm{~h}$. $\mathrm{Up}_{4} \mathrm{U}$ acts as a potent inducer of sprouting angiogenesis originating from gel-embedded EC spheroids (Figure 3.F).

We were interested to elucidate by which intracellular pathway $\mathrm{Up}_{4} \mathrm{U}$ can mediate proliferation. We tested potential activation of Mapkinases and can show that in a time-dependent way $\mathrm{Up}_{4} \mathrm{U}$ activates p38, MEK1, ERK1/2 and Akt with a maximal stimulation after $10 \mathrm{~min}$ (Figure 4.A). In the presence of U0126 (MEK1-inhibitor), SB202190 (p38 inhibitor), PD98059 (Erkl/2 inhibitor), and GSK690693 (Akt-inhibitor), $\mathrm{Up}_{4} \mathrm{U}$ induced proliferation was significantly reduced, indicating that all mapkinase activation is involved in the proliferative response (Figure 4.B).

Finally, the in-vivo/ex-vivo ability of endothelial cells to release $\mathrm{Up}_{4} \mathrm{U}$ was assessed in freshly isolated rat aortic rings (Figure 4.G). $\mathrm{Up}_{4} \mathrm{U}$ was detected in the $24 \mathrm{~h}$ conditioned media of freshly isolated aortic rings and in a subsequent $45 \mathrm{~min}$. control conditioned media. $\mathrm{Up}_{4} \mathrm{U}$ content further increased following stimulation with either calcium ionophore (A23187) or endothelin 1.

\section{Discussion}

$\mathrm{Up}_{4} \mathrm{U}$ is a potent angiogenic factor in human vascular endothelial cells. We tested the actions of $\mathrm{Up}_{4} \mathrm{U}$ on three major mechanisms contributing to angiogenesis, namely migration, proliferation, and tube formation [29]. $\mathrm{Up}_{4} \mathrm{U}$ directly increased the proliferation rate of endothelial cells, stimulated migration and tube formation, sprouting of endothelial cells and potentiated the proliferative effects of a peptidic growth factor, PDGF on vascular smooth muscle cell proliferation. Migration is only stimulated with higher $\mathrm{Up}_{4} \mathrm{U}$ concentrations, which are not present in the plasma of healthy humans, but may be reached locally upon release of $\mathrm{Up}_{4} \mathrm{U}$ into the extracellular space. In order to asses the in vivo relevance of these findings, $\mathrm{Up}_{4} \mathrm{U}$ was assayed in the supernatants of freshly isolated aortic rings. Aortic rings released $\mathrm{Up}_{4} \mathrm{U}$ into the supernatant under non-stimulated conditions and known inducers of $\mathrm{Up}_{4} \mathrm{U}$ release further increased the $\mathrm{Up}_{4} \mathrm{U}$ content in conditioned media.

$\mathrm{Up}_{4} \mathrm{U}$ belongs to the group of dinucleoside polyphosphates, which regulates vascular tone [15], vascular smooth muscle proliferation [30-32], platelet aggregation [33] and mesangial cell proliferation [34]. $\mathrm{Up}_{4} \mathrm{U}$ is the first member of family of a dinucleoside polyphosphates which has only pyrimidine-containing nucleosides at both ends. Dinucleoside polyphosphates were isolated from body fluids and cells like platelets [35,36], brain [37], heart [38], plasma [39] or endothelial cells [15]. Dinucleoside polyphosphates are released into the circulation from several cell types, including activated platelets $[36,40,41]$, chromaffin cells of the adrenal glands [37,42-44], tubular cells [32,45] or from synaptic vesicles [46]. Furthermore, dinucleoside polyphosphates are important neurotransmitter molecules in the nervous system [47]. Dinucleoside polyphosphates occur in human plasma at concentrations sufficient to cause vasoregulatory effects [39], which are significantly increased in pathophysiological conditions, like hypertension [48]. The very last one was $\mathrm{Up}_{4} \mathrm{~A}$ which acts as potent endothelium derived contracting factor [15]. The actions of the currently known dinucleoside polyphosphates have been extensively reviewed recently [49]. 
A

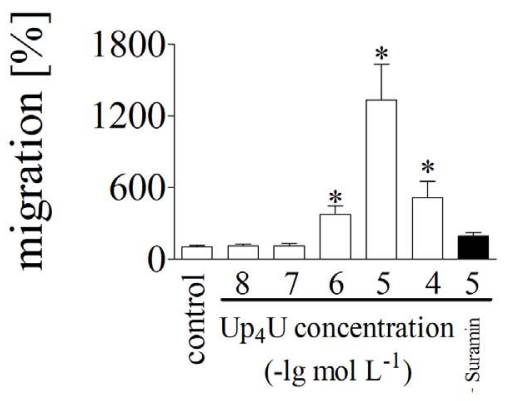

$\mathrm{C}$

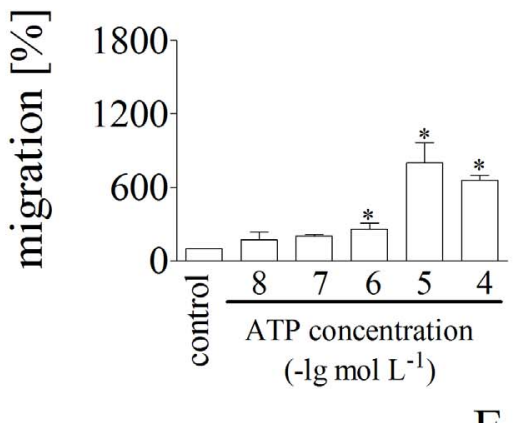

$\mathrm{E}$
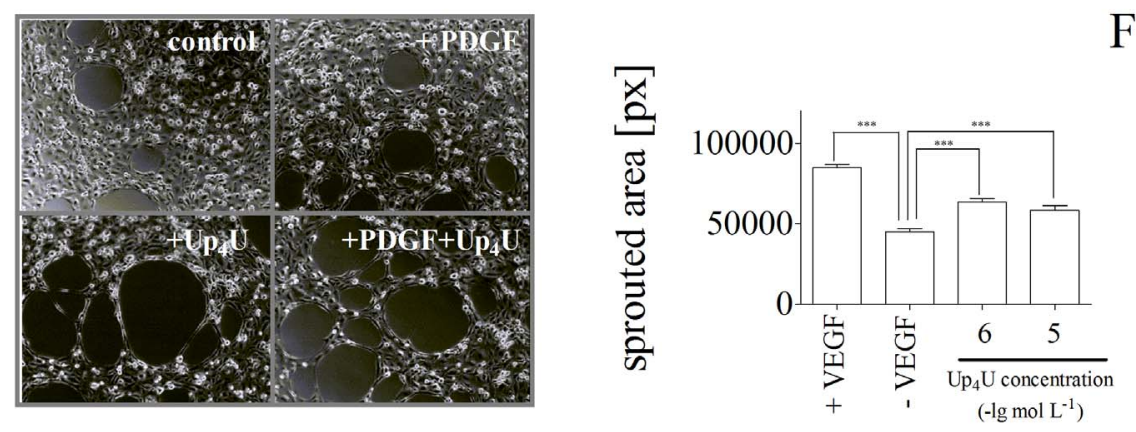

Figure 3. (A)Effect of increasing $U p_{4} U$ concentrations on migration rate of endothelial cells in the absence (open bar) and presence (filled bar) of suramin $(n=6)$. (B)Effect of increasing UTP concentrations on migration rate of endothelial cells $(n=3)$. (C)Effect of increasing ATP concentrations on migration rate of endothelial cells $(n=3)$. (D) Effect of increasing Up $\mathrm{p}_{4} \mathrm{U}$ concentrations on tube-formation rate of endothelial cells $\left(510^{-5} \mathrm{~mol}^{-1}\right.$ $U p_{4} \mathrm{U}$ and $10^{-7} \mathrm{~mol} \mathrm{~L}^{-1}$ PDGF as indicated in the figure; $n=12$ ). (E)Effect of $U p_{4} \mathrm{U}$ on phenotype of endothelial cells. Representative microscopic

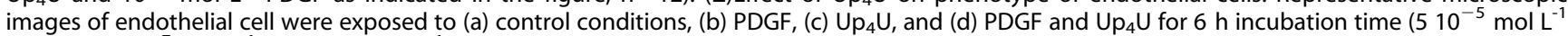
$\mathrm{Up}_{4} \mathrm{U}$ and $10^{-7} \mathrm{~mol} \mathrm{~L}^{-1}$ PDGF (10ng ml $\left.{ }^{-1}\right)$ ). (F)Quantification of 3-dimensional in vitro angiogenesis with collagen gel-embedded spheroids of EC. Spheroids were embedded into collagen gels with $U p_{4} U$ and with or without VEGF. The cumulative length of all the sprouts originating from an individual spheroid was quantified after $24 \mathrm{~h}$ by semiautomatic image analysis. doi:10.1371/journal.pone.0068575.g003

Recently the vascular endothelial growth factor receptor 2 (VEGFR2) was described as capable of synthesizing the dinucleoside polyphosphates uridine adenosine tetraphosphate $\left(\mathrm{Up}_{4} \mathrm{~A}\right)$, diadenosine polyphosphates $\left(A_{\mathrm{x}} \mathrm{A}\right.$; with $\left.\mathrm{x}=2-6\right)$, adenosine guanosine polyphosphates (Ap $\mathrm{G}$; with $\mathrm{x}=2-6$ ) as well as diguanosine polyphosphates $\left(\mathrm{Gp}_{\mathrm{x}} \mathrm{G}\right.$; with $\left.\mathrm{x}=2-6\right)$ [50]. Therefore, it is likely that $\mathrm{Up}_{4} \mathrm{U}$ is synthesized by the VEGFR2 in-vivo, too.

Which receptors mediate the $\mathrm{Up}_{4} \mathrm{U}$ effects? Endothelial cells migration is significantly inhibited by suramin. From the P2Y receptors expressed in endothelial cells, suramin inhibits the P2Y1, P2Y2 and P2Y6, but not the P2Y4 subtype [51]. Suramin markedly inhibits migration in our experiments. On the other hand RB2, which is known to block both $\mathrm{P} 2 \mathrm{Y} 1$ and $\mathrm{P} 2 \mathrm{Y} 6$ receptors [51], did not show a significant effect. Therefore, the
P2Y2 receptor appears to be the subtype involved in the stimulatory effects of $\mathrm{Up}_{4} \mathrm{U}$ on endothelial cells migration. The non-significant effect of PPADS, which is an inhibitor of P2Y1 receptors [51], is also compatible with this view. ATP $\gamma \mathrm{S}$ is a selective activator of $\mathrm{P} 2 \mathrm{Y} 2$ receptors and can mimic the effect of $\mathrm{Up}_{4} \mathrm{U}$ on proliferation. $\mathrm{Up}_{4} \mathrm{U}$ induced proliferation is intracellularly mediated by Mapkinase activation.

In contrast to VEGF and adenosine, which are produced by a multitude of tissues primarily as a response to hypoxia [52,53], $\mathrm{Up}_{4} \mathrm{U}$ seems to be produced mainly by endothelial cells in an autocrine fashion. Moreover, the experiments using shear stress suggest that hemodynamic rather than metabolic factors regulate $\mathrm{Up}_{4} \mathrm{U}$ secretion. Thus with respect to production and regulation, 


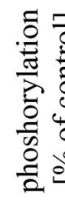

4000

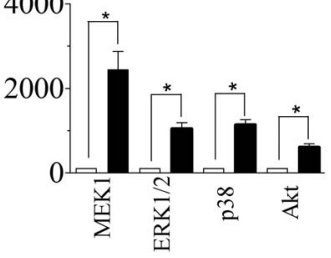

150
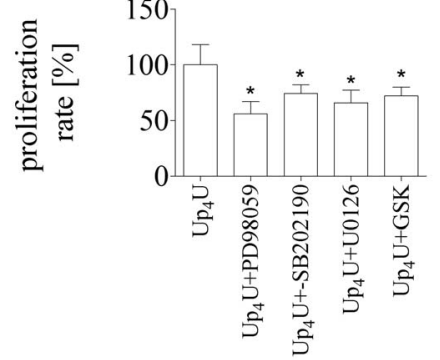

$\mathrm{C}$
B

A

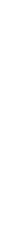

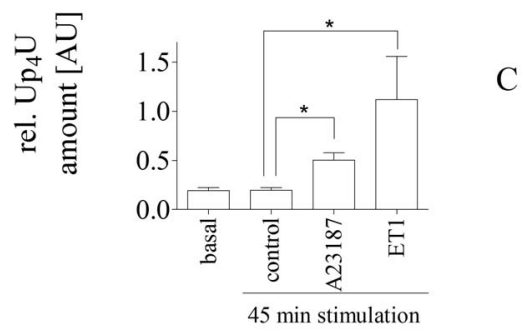

Figure 4. (A)Effect of $\mathrm{Up}_{4} \mathrm{U}$ on phosphorylation of MAPK. Phosphorylation of MEK1, ERK1/2, Akt, and p38 measured by Luminex ${ }^{\mathrm{TM}}$ technique before (open bar) and after stimulation with $\mathrm{Up}_{4} \mathrm{U}$ for $10 \mathrm{~min}$ (filled bar). Ratio of phospho/total were normalized to protein content of the lysates and demonstrated as percent stimulation relative to control $\left({ }^{*} p<0.05 ; n=5\right)$. (B)Effect of PD98059, U0126, SB2021902, and GSK on $\mathrm{Up}_{4} \mathrm{U}$ induced proliferation rate in vascular smooth muscle cells $(\mathbf{C}) \mathrm{Up}_{4} \mathrm{U}$ amount of secretome from in-vivo/ex-vivo stimulated aortic rings. $\left({ }^{*} \mathrm{p}<0.05 ; \mathrm{n}=4\right)$.

doi:10.1371/journal.pone.0068575.g004

$\mathrm{Up}_{4} \mathrm{U}$ differs from the most important known peptidic and nonpeptidic angiogenic factors.

It would appear that $\mathrm{Up}_{4} \mathrm{U}$ acts synergistically with peptidic growth factors. $\mathrm{Up}_{4} \mathrm{U}$ stimulates vascular smooth muscle cell proliferation only when applied in combination with a peptidic growth factor like PDGF, but this costimulatory effect is even present with nanomolar concentrations, which are also found in human plasma.

\section{References}

1. Kim YW, West XZ, Byzova TV (2013) Inflammation and oxidative stress in angiogenesis and vascular disease. J Mol Med (Berl) 91: 323-328.

2. Potente M, Gerhardt H, Carmeliet P (2011) Basic and therapeutic aspects of angiogenesis. Cell 146: 873-887.

3. Jain RK (2003) Molecular regulation of vessel maturation. Nat Med 9: 685-693.

4. Noonan DM, De Lerma Barbaro A, Vannini N, Mortara L, Albini A (2008) Inflammation, inflammatory cells and angiogenesis: decisions and indecisions. Cancer Metastasis Rev 27: 31-40.

5. Hanahan D, Weinberg RA (2011) Hallmarks of cancer: the next generation. Cell 144: 646-674.

6. Motz GT, Coukos G (2011) The parallel lives of angiogenesis and immunosuppression: cancer and other tales. Nat Rev Immunol 11: 702-711.

7. Zisa D, Shabbir A, Mastri M, Taylor T, Aleksic I, et al. (2011) Intramuscular VEGF activates an SDF1-dependent progenitor cell cascade and an SDF1independent muscle paracrine cascade for cardiac repair. Am J Physiol Heart Circ Physiol 301: H2422-2432.

8. Segar CE, Ogle ME, Botchwey EA (2013) Regulation of angiogenesis and bone regeneration with natural and synthetic small molecules. Curr Pharm Des.
To what extent are the angiogenic effects of $\mathrm{Up}_{4} \mathrm{U}$ different from those of the nucleotides known to affect angiogenesis like ATP and UTP? Our experiments show that both ATP and UTP do not stimulate VSMC cells growth, either alone or in combination with PDGF. Both ATP and UTP stimulate migration, but the effects are markedly less than that of $\mathrm{Up}_{4} \mathrm{U}$. Therefore, although UTP could be generated as a split product of $\mathrm{Up}_{4} \mathrm{U}$, it seems unlikely that $\mathrm{Up}_{4} \mathrm{U}$ exerts its effects by split products such as UTP. Additionally, $\mathrm{Up}_{4} \mathrm{U}$ effects sprouting effects of endothelial cells.

What is the role of $\mathrm{Up}_{4} \mathrm{U}$-induced angiogenesis in the context of other angiogenic factors? $\mathrm{Up}_{4} \mathrm{U}$ is secreted from endothelial cells upon stimulation by shear stress. This mechanism of release suggests that $\mathrm{Up}_{4} \mathrm{U}$ may mediate angiogenic stimuli from vascular endothelial cells. On the other hand, adenosine is known to mediate hypoxia-induced angiogenesis [54]. Also VEGF is secreted mainly as a response to hypoxia [55]. $\mathrm{Up}_{4} \mathrm{U}$ may be regarded as a further angiogenic factor secreted upon other stimuli than the known angiogenic factors and possibly modulating their actions.

In summary $\mathrm{Up}_{4} \mathrm{U}$ is a novel human endothelium-derived angiogenic nucleotide, which acts on human endothelial cell migration, proliferation, tube formation and induce sprouting of endothelial cells. With respect to VSMC proliferation $\mathrm{Up}_{4} \mathrm{U}$ acts synergistically with peptidic growth factors. These autocrine angiogenic effects of $\mathrm{Up}_{4} \mathrm{U}$ are mainly regulated by stimulation of EC.

\section{Supporting Information}

Figure S1 (A) Reversed phase chromatography of deproteinized supernatants from stimulated endothelial cells. The fraction for further fractionation is labelled by an arrow. (B) Affinity chromatography of the fraction labelled by an arrow in Figure S1.A by using a phenylboronate affinity column. The fraction for further fractionation is labelled by an arrow. (X) Reversed phase chromatography of the fraction labelled by an arrow in Figure S1.B. The fraction for mass-spectrometric analysis is labelled by an arrow. $(\Delta)$ Molecular structure of diuridine tetraphosphate.

(TIF)

\section{Author Contributions}

Conceived and designed the experiments: VJ M. Tölle MvdG KL BF AO WZ JJ. Performed the experiments: VJ M. Tölle M. Tepel TNAT MS KL DJ BF AO NMDS JJ. Analyzed the data: VJ M. Tepel MvdG KL MG AO WZ JJ. Wrote the paper: VJ MvdG KL AO WZ JJ.

9. Coultas L, Chawengsaksophak K, Rossant J (2005) Endothelial cells and VEGF in vascular development. Nature 438: 937-945.

10. Ferguson JE 3rd, Kelley RW, Patterson G (2005) Mechanisms of endothelial differentiation in embryonic vasculogenesis. Arterioscler Thromb Vasc Biol 25: 2246-2254.

11. Flick B, Klug S (2006) Whole embryo culture: an important tool in developmental toxicology today. Curr Pharm Des 12: 1467-1488.

12. Nagase M, Nagase T, Koshima I, Fujita T (2006) Critical time window of hedgehog-dependent angiogenesis in murine yolk sac. Microvasc Res 71: 85-90.

13. Xu Y, Swerlick RA, Sepp N, Bosse D, Ades EW, et al. (1994) Characterization of expression and modulation of cell adhesion molecules on an immortalized human dermal microvascular endothelial cell line (HMEC-1). J Invest Dermatol 102: 833-837.

14. Orzechowski HD, Gunther A, Menzel S, Zimmermann A, Funke-Kaiser H, et al. (2001) Transcriptional mechanism of protein kinase C-induced isoformspecific expression of the gene for endothelin-converting enzyme-1 in human endothelial cells. Mol Pharmacol 60: 1332-1342. 
15. Jankowski V, Tölle M, Vanholder R, Schönfelder G, van der Giet M, et al. (2005) Identification of uridine adenosine tetraphosphate $\left(\mathrm{Up}_{4} \mathrm{~A}\right)$ as an endothelium-derived vasoconstrictive factor. Nature Medicine 11: 223-227.

16. Jankowski J, Stephan N, Knobloch M, Fischer S, Schmaltz D, et al. (2001) Massspectrometry-linked screening of protein fractions for enzymatic activities-a tool for functional genomics. Anal Biochem 290: 324-329.

17. Morawietz H, Talanow R, Szibor M, Rueckschloss U, Schubert A, et al. (2000) Regulation of the endothelin system by shear stress in human endothelial cells. J Physiol 525 Pt 3: 761-770.

18. Sdougos HP, Bussolar SR, Dewey CFJ (1984) Secondary flow and turbulence in a cone-and-plate device. J Fluid Mech 138: 379-404.

19. Klug S, Lewandowski C, Neubert D (1985) Modification and standardization of the culture of early postimplantation embryos for toxicological studies. Arch Toxicol 58: 84-88.

20. Barnes LD, Robinson AK, Mumford CH, Garrison PN (1985) Assay of diadenosine tetraphosphate hydrolytic enzymes by boronate chromatography. Anal Biochem 144: 296-304.

21. Gobom J, Schuerenberg M, Mueller M, Theiss D, Lehrach H, et al. (2001) Alpha-cyano-4-hydroxycinnamic acid affinity sample preparation. A protocol for MALDI-MS peptide analysis in proteomics. Anal Chem 73: 434-438.

22. Jankowski V, Vanholder R, van der Giet M, Tölle M, Karadogan S, et al. (2007) Mass-spectrometric identification of a novel angiotensin peptide in human plasma. Arterioscler Thromb Vasc Biol 27: 297-302.

23. Jankowski J, Grosse-Huettmann P, Zidek W, Schlüter H (2003) Identification of dinucleoside polyphosphates by matrix-assisted laser desorption/ionisation postsource decay mass spectrometry. Rapid Commun Mass Spectrom 17: 11891194 .

24. Ng KE, Orgel EL (1987) The action of water-soluble carbodiimide on adenosine-5'-polyphosphates. Nucleic Acids Res 15: 3573-3580.

25. Jankowski J, Potthoff W, Zidek W, Schlüter H (1998) Purification of chemically synthesised dinucleoside $\left(5^{\prime}, 5^{\prime}\right)$ polyphosphates by displacement chromatography. J Chromatogr B Biomed Sci Appl 719: 63-70.

26. Korff T, Augustin HG (1998) Integration of endothelial cells in multicellular spheroids prevents apoptosis and induces differentiation. J Cell Biol 143: 13411352.

27. Korff T, Kimmina S, Martiny-Baron G, Augustin HG (2001) Blood vessel maturation in a 3-dimensional spheroidal coculture model: direct contact with smooth muscle cells regulates endothelial cell quiescence and abrogates VEGF responsiveness. FASEB J 15: 447-457.

28. Valdes TI, Kreutzer D, Moussy F (2002) The chick chorioallantoic membrane as a novel in vivo model for the testing of biomaterials. J Biomed Mater Res 62: 273-282.

29. Walsh DA (2007) Pathophysiological mechanisms of angiogenesis. Adv Clin Chem 44: 187-221.

30. Wiedon A, Tolle M, Bastine J, Schuchardt M, Huang T, et al. (2012) Uridine adenosine tetraphosphate $(\mathrm{Up} 4 \mathrm{~A})$ is a strong inductor of smooth muscle cell migration via activation of the $\mathrm{P} 2 \mathrm{Y} 2$ receptor and cross-communication to the PDGF receptor. Biochem Biophys Res Commun 417: 1035-1040.

31. Jankowski J, Hagemann J, Yoon MS, van der Giet M, Stephan N, et al. (2001) Increased vascular growth in hemodialysis patients induced by platelet- derived diadenosine polyphosphates. Kidney Int 59: 1134-1141.

32. Jankowski V, Karadogan S, Vanholder R, Nofer JR, Herget-Rosenthal S, et al. (2007) Paracrine stimulation of vascular smooth muscle proliferation by diadenosine polyphosphates released from proximal tubule epithelial cells. Kidney Int 71: 994-1000.

33. Chang H, Yanachkov IB, Michelson AD, Li Y, Barnard MR, et al. (2010) Agonist and antagonist effects of diadenosine tetraphosphate, a platelet dense granule constituent, on platelet P2Y1, P2Y12 and P2X1 receptors. Thromb Res 125: $159-165$.

34. Heidenreich S, Tepel M, Schlüter H, Harrach B, Zidek W (1995) Regulation of rat mesangial cell growth by diadenosine phosphates. J Clin Invest 95: $2862-$ 2867.
35. Jankowski J, Hagemann J, Tepel M, van der Giet M, Stephan N, et al. (2001) Dinucleotides as growth promoting extracellulary mediators: Presence of dinucleoside diphosphates $\mathrm{Ap}_{2} \mathrm{~A}, \mathrm{Ap}_{2} \mathrm{G}$ and $\mathrm{Gp}_{2} \mathrm{G}$ in releasable granlues of platelets. J Biol Chem 276: 8904-8909.

36. Jankowski J, Tepel M, van der Giet M, Tente IM, Henning L, et al. (1999) Identification and characterization of $\mathrm{P}_{1}, \mathrm{P}_{7}$-diadenosine-5'- heptaphosphate from human platelets. J Biol Chem 274: 23926-23931.

37. Pintor J, Diaz-Rey MA, Torres M, Miras-Portugal MT (1992) Presence of diadenosine polyphosphates $-\mathrm{Ap}_{4} \mathrm{~A}$ and $\mathrm{Ap}_{5} \mathrm{~A}$ - in rat brain synaptic terminals. $\mathrm{Ca}^{2+}$ dependent release evoked by 4 -aminopyridine and veratridine. Neurosci Lett 136: 141-144.

38. Hoyle CH, Ziganshin AU, Pintor J, Burnstock G (1996) The activation of P1and P2-purinoceptors in the guinea-pig left atrium by diadenosine polyphosphates. Br J Pharmacol 118: 1294-1300.

39. Jankowski J, Jankowski V, Laufer U, van der Giet M, Henning L, et al. (2003) Identification and quantification of diadenosine polyphosphate concentrations in human plasma. Arterioscler Thromb Vasc Biol 23: 1231-1238.

40. Flodgaard H, Klenow H (1982) Abundant amounts of diadenosine 5',5'-P1,P4tetraphosphate are present and releasable, but metabolically inactive, in human platelets. Biochem J 208: 737-742.

41. Schlüter H, Offers E, Brüggemann G, van der Giet M, Tepel M, et al. (1994) Diadenosine phosphates and the physiological control of blood pressure. Nature 367: 186-188.

42. Castillo CJ, Moro MA, Del Valle M, Sillero A, Garcia AG, et al. (1992) Diadenosine tetraphosphate is co-released with ATP and catecholamines from bovine adrenal medulla. J Neurochem 59: 723-732.

43. Pintor J, Torres M, Miras-Portugal MT (1991) Carbachol induced release of diadenosine polyphosphates-Ap4A and Ap5A- from perfused bovine adrenal medulla and isolated chromaffin cells. Life Sci 48: 2317-2324.

44. Rodriguez del Castillo A, Torres M, Delicado EG, Miras-Portugal MT (1988) Subcellular distribution studies of diadenosine polyphosphates - $\mathrm{Ap}_{4} \mathrm{~A}$ and $\mathrm{Ap}_{5} \mathrm{~A}$ in bovine adrenal medulla: presence in chromaffin granules. J Neurochem 51: $1696-1703$

45. Jankowski V, Patzak A, Herget-Rosenthal S, Tran TN, Lai EY, et al. (2008) Uridine adenosine tetraphosphate acts as an autocrine hormone affecting glomerular filtration rate. J Mol Med 83: 333-340.

46. Zimmermann H, Volknandt W, Wittich B, Hausinger A (1993) Synaptic vesicle life cycle and synaptic turnover. J Physiol Paris 87: 159-170.

47. Delicado EG, Miras-Portugal MT, Carrasquero LM, Leon D, Perez-Sen R, et al. (2006) Dinucleoside polyphosphates and their interaction with other nucleotide signaling pathways. Pflugers Arch 452: 563-572.

48. Jankowski V, Meyer AA, Schlattmann P, Gui Y, Zheng XL, et al. (2007) Increased Uridine Adenosine Tetraphosphate Concentrations in Plasma of Juvenile Hypertensives. Arterioscler Thromb Vasc Biol 27: 1776-1781.

49. Jankowski V, van der Giet M, Mischak H, Morgan M, Zidek W, et al. (2009) Dinucleoside polyphosphates: strong endogenous agonists of the purinergic system. Br J Pharmacol 157: 1142-1153.

50. Jankowski V, Schulz A, Kretschmer A, Mischak H, van der Giet M, et al. (2013) The enzymatic activity of the VEGFR2-receptor for the biosynthesis of dinucleoside polyphosphates. J Mol Med (in press).

51. von Kugelgen I (2006) Pharmacological profiles of cloned mammalian P2Yreceptor subtypes. Pharmacol Ther 110: 415-432.

52. Linden J (2005) Adenosine in tissue protection and tissue regeneration. Mol Pharmacol 67: 1385-1387.

53. Yla-Herttuala S, Rissanen TT, Vajanto I, Hartikainen J (2007) Vascular endothelial growth factors: biology and current status of clinical applications in cardiovascular medicine. J Am Coll Cardiol 49: 1015-1026.

54. Adair TH (2005) Growth regulation of the vascular system: an emerging role for adenosine. Am J Physiol Regul Integr Comp Physiol 289: R283-R296.

55. Holmes DI, Zachary I (2005) The vascular endothelial growth factor (VEGF) family: angiogenic factors in health and disease. Genome Biol 6: 209. 